\title{
Synthesis and characterization of biologically potent chalcone bearing 1,3,4-oxadiazole linkage
}

\author{
Hiren H. Variya ${ }^{a^{*}}$, Vikram Panchal ${ }^{a}$, Falguni G. Bhabhor ${ }^{b}$, G.R.Patel ${ }^{a}$ \\ ${ }^{a}$ Department of Chemistry, Sheth M.N.Patel Science College, Patan (Guj), India. \\ ${ }^{b}$ Department of Chemistry, Navjivan Science College, Dahod(GUJ), India \\ E-mail: hirenvariya9@yahoo.com
}

Keywords: Chalcone, 1,3,4-Oxadiazole, Anti-bacterial, Anti-fungal

\begin{abstract}
In this article, we have described to design and synthesized a series of substituted chalcone based 1,3,4-oxadiazole derivatives. Titled compounds (E)-S-(-5-phenyl-1,3,4-oxadiazol-2yl) 2-(4-(3-(5-methyl-3oxo-2(p-tolyl)-2,3-dihydro-1H-pyrazol-4-yl)-3-oxoprop-1-en-1-yl)phenoxy) etanethioate ( III $_{\mathbf{1 - 6}}$ ) were synthesized using of derivatives of S-(-5-phenyl-1,3,4 oxadiazole-2-yl)2chloroethaethioate $\left(\mathbf{I}_{\mathbf{1 - 6}}\right)$ were reacted with (E)-4-(3-(4-hydroxyphenyl)acryloyl)-5-methyl-2(ptolyl)-1H-pyrazol-3(2H)-one (II) in presence of $\mathrm{K}_{2} \mathrm{CO}_{3}$ in DMF as a solvent. The synthesized compounds were evaluated for their antimicrobial activity. The newly synthesized compounds were characterized by analytical and spectral (IR, ${ }^{1} \mathrm{H}$ NMR, and LC-MS) Methods.
\end{abstract}

\section{INTRODUCTION}

The versatility of chalcone and its wide range of applicability in medicinal chemistry have attracted scientists all over the globe to concentrate their research around it. They consist of openchain flavonoids in which the two aromatic rings are joined by a three carbon chain [1]. Chalcones are natural biocides [2] and well known as intermediates for synthesizing of various heterocycles which have impressive array of biological activities; antibacterial [3], antiviral [4], antiinflammatory [5], antiulcerative [6], antimalarial [7], anticancer [8].In addition, benzofuran derivatives are nowadays an important class of organic compounds that occur in a great number of natural products [9].

The small nitrogen and oxygen containing molecules have been under investigation since long because of their important medicinal properties. 1,3,4-oxadiazole is commonly utilized pharmacophore has been subjected to extensive study in the recent years due to their metabolic profile and ability to engage in hydrogen bonding with receptor site. 1,3,4-Oxadiazoles are an important class of heterocyclic compounds with a wide range of biological activities such as antiviral [10], antimicrobial [11], antineoplastic [12], fungicidal [13], anticancer [14,15], inhibition of tyrosinase [16], They are also useful intermediates in organic synthesis [17] and widely employed as electron transporting and hole-blocking materials.

In the present communication, we report here a series of hybrid heterocyclic scaffolds by clubbing chalcone with 1,3,4-oxadiazole [18], In this present study. The structures of the various synthesized compounds were assigned on the basis of infrared (IR), proton nuclear magnetic resonance spectroscopy $\left({ }^{1} \mathrm{H}-\mathrm{NMR}\right)$ spectral data, and elemental analysis. 
Step-1 Synthesis of S-(-5-phenyl-1,3,4 oxadiazole-2-yl)2-chloroethaethioate (I-6)

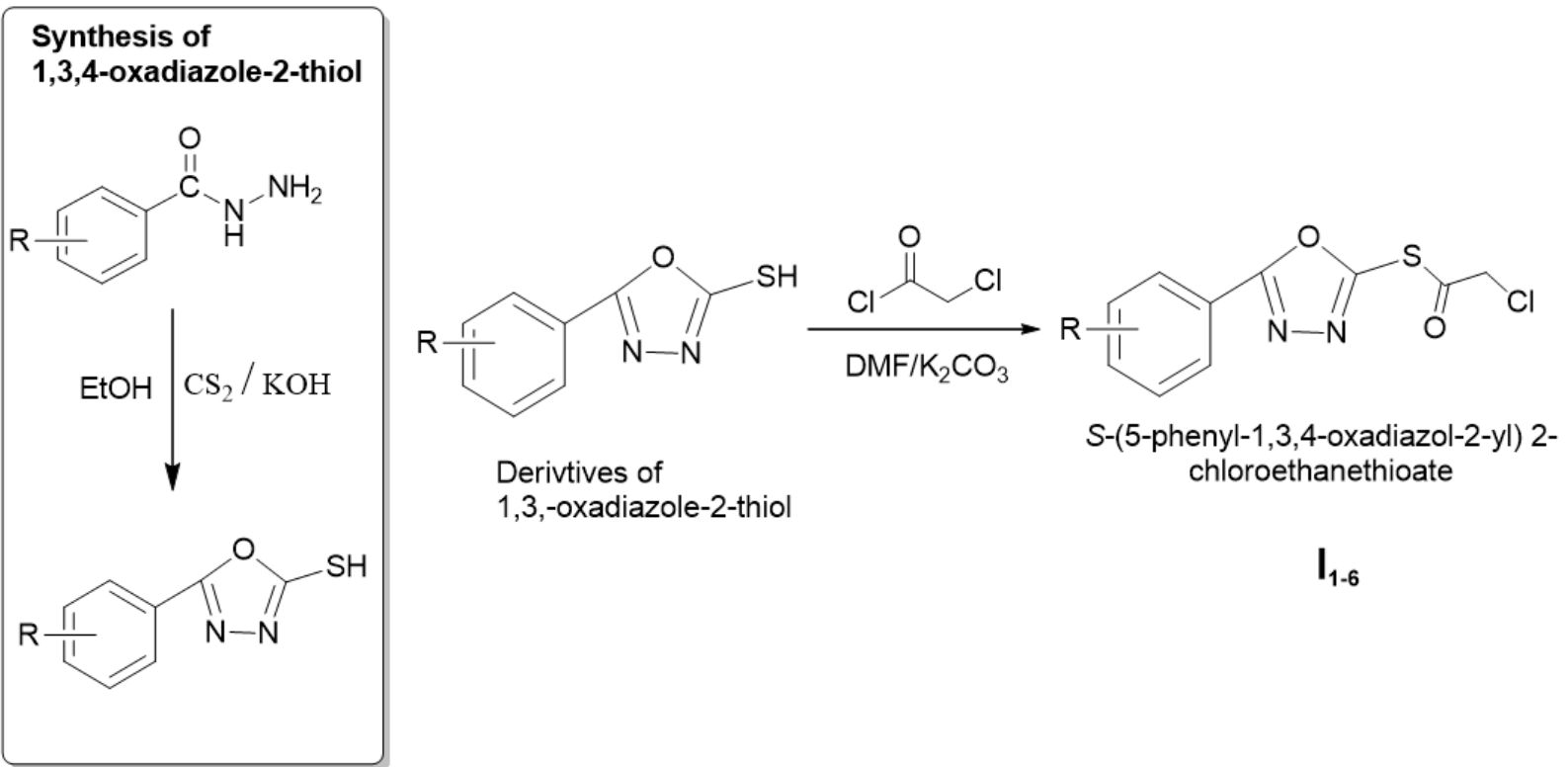

Step-2 Synthesis of (E)-4-(3-(4-hydroxyphenyl)acryloyl)-5-methyl-2(p-tolyl)-1H-pyrazol-3(2H)one (II)<smiles>CC(=O)c1c(C)[nH]n(-c2ccc(C)cc2)c1=O</smiles>

4-acetyl-5-methyl-2-(p-tolyl)-1H-pyrazol-3(2H)-one

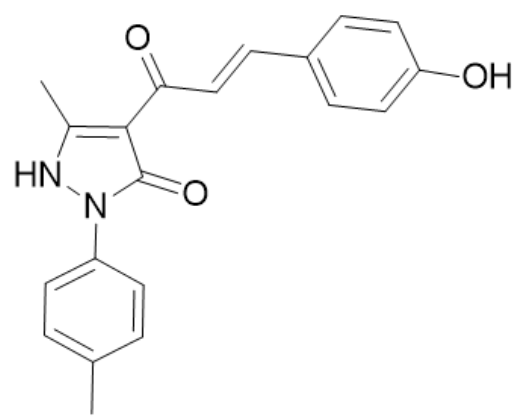

(E)-4-(3-(4-hydroxyphenyl)acryloyl)-5methyl-2-(p-tolyl)-1H-pyrazol-3(2H)-one 


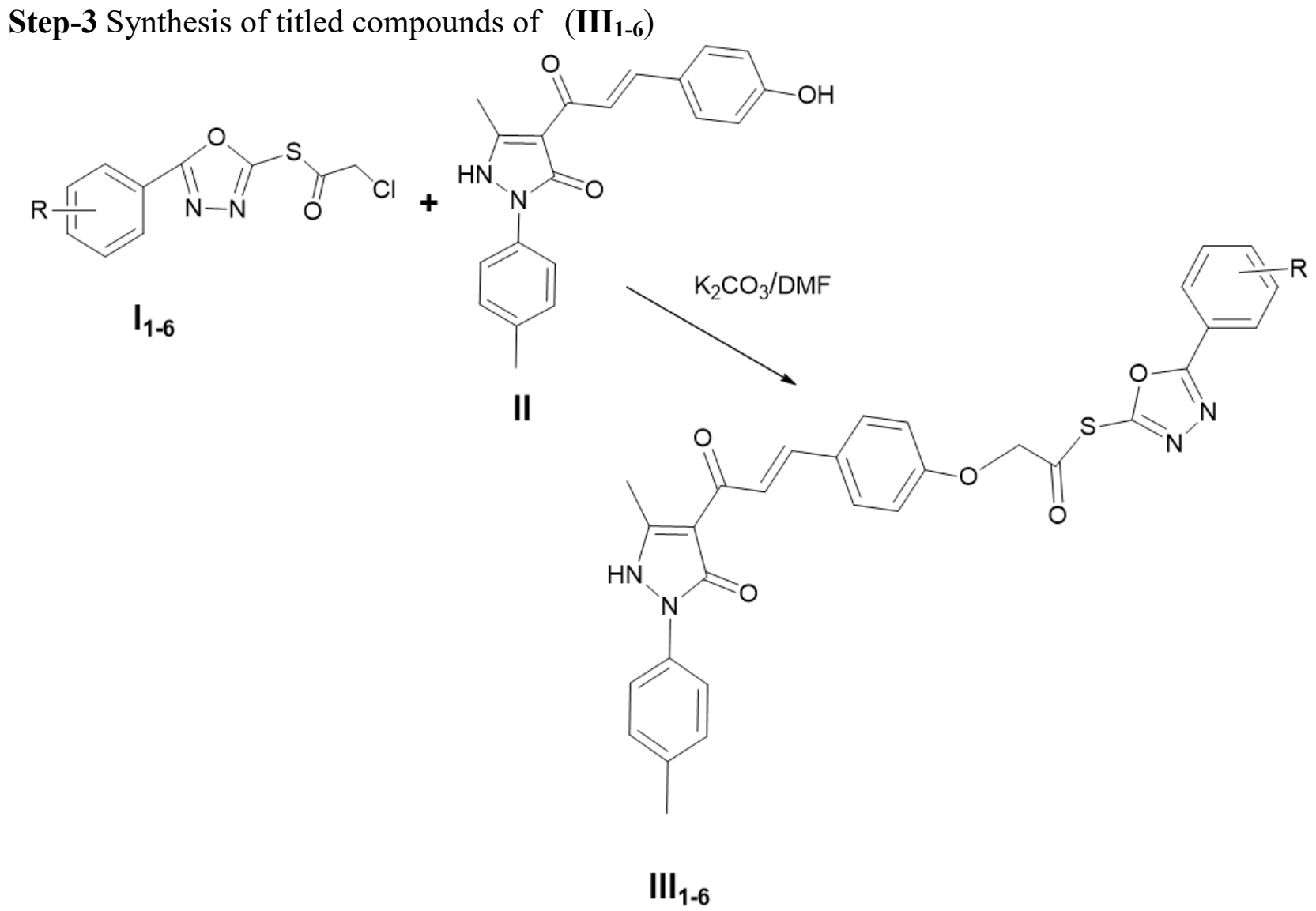

Where $\mathrm{R}=$<smiles>CC(C)C(=O)c1ccncc1</smiles><smiles>CC(C)C(=O)c1cccnc1</smiles><smiles>CC(C)C(=O)c1ccc(F)cc1</smiles><smiles>Cc1ccc(C(=O)C(C)C)cc1</smiles><smiles>CCC(=O)c1ccccc1C</smiles>

5<smiles>CC(C)C(=O)c1cccc([N+](=O)[O-])c1</smiles>

6

Scheme-1 Synthesis of compounds of $\left(\right.$ III $\left._{1-6}\right)$

\section{RESULT AND DISCUSSION}

The formulation of the titled compound ( $\left.\mathbf{I I I}_{\mathbf{1 - 6}}\right)$ was archived in three steps. Initially synthesis of different derivatives of S-(-5-phenyl-1,3,4 oxadiazole-2-yl)2-chloroethaethioate ( $\left.\mathbf{I}_{1-6}\right)$ was under taken by reacting different 1,3,4-oxadiazole-2-thiol in presence of Chloro acetyl chloride (CAC) using DMF as solvent. Simultaneously of Synthesis of (E)-4-(3-(4-hydroxyphenyl) acryloyl)-5methyl-2(p-tolyl)-1H-pyrazol-3(2H)-one (II) were prepared by reacting $1 \mathrm{H}$ pyrazole containing acetaphenone with p-hydroxy benzaldehyde where $\mathrm{NaOH}$ was used as a base catalyst. The obtained intermediates $\left(\mathbf{I}_{\mathbf{1}-\mathbf{6}}\right)$ and of (E)-4-(3-(4-hydroxyphenyl)acryloyl)-5-methyl-2( $p$-tolyl)-1H-pyrazol$3(2 \mathrm{H})$-one (II) were reacted in presence of $\mathrm{K}_{2} \mathrm{CO}_{3}$ using DMF as a suitable solvent, Which resulted in the formulation of titled compounds $\left(\mathbf{I I I}_{\mathbf{1 - 6}}\right)$ in good yield. The elemental analysis of synthesis compounds are indicated in Table-1

\section{CHARACTERIZATION}

IR spectra

IR spectra of the compound (III) Synthesis of (E)-S-(5-phenyl-1,3,4oxadiazole-2-yl)2-(4-(3-(4-(5methyl-3-oxo-2-(p-tolyl)yl)-2,3dihydro-1H-pyrazol-4yl)-3-oxoprop-1-en-1yl)phenoxy)ethanethioate ( III $_{1}$ ) have given a sharp absorption peak at $2983 \mathrm{~cm}^{-1}$ the steching vibration foe the aromatic-C-H group. A weak absorption stretching vibration band observed at $2756 \mathrm{~cm}^{-1}$ confirmed the presence of methylene group in the final motifs. The carbonyl functional group present in vicinity to the chalcone $(-\mathrm{CH}=\mathrm{CH}-)$ has shown a sharp and intense absorption peak at $1663 \mathrm{~cm}^{-}$ 
${ }^{1}$,Another stretching vibration at $1593 \mathrm{~cm}^{-1}$. Confirmation $-\mathrm{CH}=\mathrm{CH}$ - (chalcone formation) near the carbonyl group. The present of $(-\mathrm{C}=\mathrm{C}-)$ in the aromatic ring was proved by the presence of an absorption peak at $1537 \mathrm{~cm}^{-1}$. The formation of oxadiazole nucleus was confirmed by the presence of two absorption band at 1035 and $1243 \mathrm{~cm}^{-1}$ indicating (-C-O-C-) linkage in the structure. Thus, IR spectral data support the formation of the desire motifs (III $1-6$ )

\section{$\mathrm{H}^{1} \mathrm{NMR}$}

We have consider compound $\left(\mathbf{I I I}_{\mathbf{1}}\right)$ and try to evaluated the proton NMR spectra data two broad but singlet peaks examined at $\delta=2.12$ and $\delta=2.20$ indicated the presence of methyl group in final structure. A peak appearing particularly at $\delta=4.69$ confirmed the proton of methylene group in the final structure. The presence of the protons intact with the two carbon atoms each of the chalcone group was confirmed by the presence of two doublets at $\delta=7.15$ and $\delta=7.88$, respectively. The proton belonging to aromatic rings of the final molecule were found to correspond between the $\delta$ values 7.08-8.93.

\section{MATERIAL AND METHOD}

Equipment's, Material and Physical measurements

Melting points were determined in open capillary tubes and were uncorrected. The IR spectra were recorded by a Perkin-Elmer 237 spectrophotometer and 1H NMR was recorded in DMSO with TMS as internal standard on Bruker. AM 400 Mass spectra were recorded on M S route JMS 600H.The completion reaction was monitored on TLC plates purchased from Merck (TLC silica gel 60 $\mathrm{F}_{254}$ ) and all appropriate solvents were used as mobile phase. All the synthesized compounds were purified by recrystallization method. All the chemicals and solvents were A.R Grade and were used without further purification.

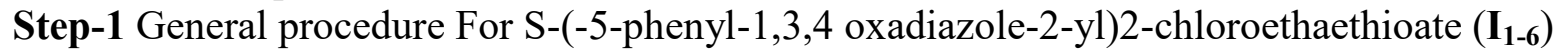
Take $(0.01 \mathrm{~mol})$ 1,3,4-oxadiazole-2-thiol in $10 \mathrm{ml}$ DMF. Dissolve it then add $(0.3$ to $0.5 \mathrm{~g}) \mathrm{K}_{2} \mathrm{CO}_{3}$ \& stir it for $15 \mathrm{~min}$. Then add $0.01 \mathrm{~mol} \mathrm{CAC} \mathrm{drop} \mathrm{wise} \mathrm{at} 0-5^{\circ} \mathrm{C}$ and stir the mix for $2 \mathrm{hr}$.at room temp. The formation of titled intermediate was confirmed by observing the TLC using ethyl-acetate: hexane as a mobile phase. After completion of reaction pour the mix in cold water \& collect the product.

Step-2 Preparation for (E)-4-(3-(4-hydroxyphenyl) acryloyl)-5-methyl-2(p-tolyl)-1H-pyrazol3 (2H)-one (II)

A mixture of aromatic aldehyde $(0.01 \mathrm{~mol})$ and 4-acetyl-3-methyl-1-(tolyl)-Pyrazole-5(4H)-one $(0.01 \mathrm{~mol})$ in $95 \%$ ethanol $(20 \mathrm{ml})$ were mixed in round bottom flask and $10 \mathrm{ml}$ of $60 \%$ of aq. Sodium hydroxide solution added drop wise. Resulting mix was stirred for at $5-10^{\circ} \mathrm{C}$, poured into crushed ice and acidified with dilute $\mathrm{HCl}$. The formation of titled intermediate was confirmed by observing the TLC using ethyl-acetate: hexane as a mobile phase.

Step-3 Preparation for titled compounds

(0.01 mol)(E)-4-(3-(4-hydroxyphenyl)acryloyl)-5-methyl-2(p-tolyl)-1H-pyrazol-3(2H)-one-(II) dissolve in DMF. To this solution different derivative were added $\mathrm{K}_{2} \mathrm{CO}_{3}(0.02 \mathrm{~mol})$ was added to the above mix Then it was allowed to stir for $4 \mathrm{hr}$ at room temp. The formation of titled intermediate was confirmed by observing the TLC using ethyl-acetate: hexane as a mobile phase. The completion of reaction was monitored using TLC plate.

(E)-S-(5-pyridin-1,3,4oxadiazole-4-yl)2-(4-(3-(4-(5-methyl-3-oxo-2-(p-tolyl)yl)-2,3dihydro-1Hpyrazol-4yl)-3-oxoprop-1-en-1yl)phenoxy)ethan-ethioate (III)

IR: $2893 \mathrm{~cm}^{-1}$ (C-H str. Of Ar.), $2756 \mathrm{~cm}^{-1}$ (methylene), $1663 \& 1593$ (-CH=CH- of Chalcone), $1537 \mathrm{Cm}^{-1}$ (-C=C- of Ar.), $1035 \& 1243 \mathrm{Cm}^{-1}$ (-C-O-C- Of Oxadiazole) Mass $(\mathrm{m} / \mathrm{z}): 553.4\left(\mathrm{M}^{+}\right)$ NMR: $2.12 \& 2.20$ (s, 3H), 4.69 (s, 2H, methylene), $7.15 \& 7.88(\mathrm{~d}, 1 \mathrm{H}), 7.77-8.10(4 \mathrm{H}, \mathrm{d}, \mathrm{Ar}-\mathrm{H})$ (E)-S-(5-pyridin-1,3,4oxadiazole-3-yl)2-(4-(3-(4-(5-methyl-3-oxo-2-(p-tolyl)yl)-2,3dihydro-1Hpyrazol-4yl)-3-oxoprop-1-en-1yl)phenoxy)ethan-ethioate ( $\left.\mathbf{I I I}_{2}\right)$ 
IR: $2891 \mathrm{~cm}^{-1}$ (C-H str. Of Ar.), $2759 \mathrm{~cm}^{-1}$ (methylene), 1663 \& 1593 (-CH=CH- of Chalcone), $1537 \mathrm{Cm}^{-1}$ (-C=C- of Ar.), $1037 \& 1243 \mathrm{Cm}^{-1}$ (-C-O-C- Of Oxadiazole) Mass $(\mathrm{m} / \mathrm{z}): 553.6\left(\mathrm{M}^{+}\right)$ NMR: $2.12 \& 2.20(\mathrm{~s}, 3 \mathrm{H}), 4.69(\mathrm{~s}, 2 \mathrm{H}$, methylene), $7.15 \& 7.88(\mathrm{~d}, 1 \mathrm{H}), 7.77-8.12(4 \mathrm{H}, \mathrm{d}, \mathrm{Ar}-\mathrm{H})$ (E)-S-(5-(4-flourophenyl)-1,3,4oxadiazole-2-yl)2-(4-(3-(4-(5-methyl-3-oxo-2-(p-tolyl)yl)2,3dihydro-1H-pyrazol-4yl)-3-oxoprop-1-en-1yl)phenoxy)ethan-ethioate ( III $\left._{\mathbf{3}}\right)$

IR: $2890 \mathrm{~cm}^{-1}$ (C-H str. Of Ar.), $2757 \mathrm{~cm}^{-1}$ (methylene), $1661 \& 1594$ (-CH=CH- of Chalcone), $1539 \mathrm{Cm}^{-1}$ (-C=C- of Ar.), $1031 \& 1245 \mathrm{Cm}^{-1}$ (-C-O-C- Of Oxadiazole) Mass $(\mathrm{m} / \mathrm{z}): 571.6\left(\mathrm{M}^{+}\right)$ NMR: $2.16 \& 2.23(\mathrm{~s}, 3 \mathrm{H}), 4.65(\mathrm{~s}, 2 \mathrm{H}$, methylene), $7.17 \& 7.86(\mathrm{~d}, 1 \mathrm{H}), 7.74-8.11(4 \mathrm{H}, \mathrm{d}, \mathrm{Ar}-\mathrm{H})$ (E)-S-(5-(4-tolyl)-1,3,4oxadiazole-2-yl)2-(4-(3-(4-(5-methyl-3-oxo-2-(p-tolyl)yl)-2,3dihydro-1Hpyrazol-4yl)-3-oxoprop-1-en-1yl)phenoxy)ethan-ethioate $\left(\mathbf{I I I}_{4}\right)$

IR: $2893 \mathrm{~cm}^{-1}$ (C-H str. Of Ar.), $2755 \mathrm{~cm}^{-1}$ (methylene), $1662 \& 1593$ (-CH=CH- of Chalcone), $1537 \mathrm{Cm}^{-1}$ (-C=C- of Ar.), $1034 \& 1245 \mathrm{Cm}^{-1}$ (-C-O-C- Of Oxadiazole) Mass $(\mathrm{m} / \mathrm{z}): 567.1\left(\mathrm{M}^{+}\right)$ NMR: $2.10 \& 2.22(\mathrm{~s}, 3 \mathrm{H}), 4.71(\mathrm{~s}, 2 \mathrm{H}$, methylene), $7.13 \& 7.89(\mathrm{~d}, 1 \mathrm{H}), 7.78-8.10(4 \mathrm{H}, \mathrm{d}, \mathrm{Ar}-\mathrm{H})$ (E)-S-(5-(o-tolyl)-1,3,4oxadiazole-2-yl)2-(4-(3-(4-(5-methyl-3-oxo-2-(p-tolyl)yl)-2,3dihydro-1Hpyrazol-4yl)-3-oxoprop-1-en-1yl)phenoxy)ethan-ethioate (III)

IR: $2893 \mathrm{~cm}^{-1}$ (C-H str. Of Ar.), $2755 \mathrm{~cm}^{-1}$ (methylene), $1662 \& 1593$ (-CH=CH- of Chalcone), $1537 \mathrm{Cm}^{-1}$ (-C=C- of Ar.), $1034 \& 1245 \mathrm{Cm}^{-1}$ (-C-O-C- Of Oxadiazole) Mass $(\mathrm{m} / \mathrm{z}): 567.1\left(\mathrm{M}^{+}\right)$ NMR: $2.10 \& 2.22(\mathrm{~s}, 3 \mathrm{H}), 4.71(\mathrm{~s}, 2 \mathrm{H}$, methylene), $7.13 \& 7.89(\mathrm{~d}, 1 \mathrm{H}), 7.78-8.10(4 \mathrm{H}, \mathrm{d}, \mathrm{Ar}-\mathrm{H})$

(E)-S-(5-(3-nitrophenyl)-1,3,4oxadiazole-2-yl)2-(4-(3-(4-(5-methyl-3-oxo-2-(p-tolyl)yl)2,3dihydro-1H-pyrazol-4yl)-3-oxoprop-1-en-1yl)phenoxy)ethan-ethioate (III $\mathbf{6})$

IR: $2891 \mathrm{~cm}^{-1}$ (C-H str. Of Ar.), $2756 \mathrm{~cm}^{-1}$ (methylene), $1660 \& 1596$ (-CH=CH- of Chalcone), $1535 \mathrm{Cm}^{-1}$ (-C=C- of Ar.), $1033 \& 1243 \mathrm{Cm}^{-1}$ (-C-O-C- Of Oxadiazole) Mass $(\mathrm{m} / \mathrm{z}): 598.7\left(\mathrm{M}^{+}\right)$ NMR: $2.14 \& 2.22(\mathrm{~s}, 3 \mathrm{H}), 4.69(\mathrm{~s}, 2 \mathrm{H}$, methylene), $7.11 \& 7.89(\mathrm{~d}, 1 \mathrm{H}), 7.77-8.12$ (4H, d, Ar$\mathrm{H}) \mathrm{sS}$

Table-1 Analytical data and Elemental analysis of compounds (III 1-6)

\begin{tabular}{|c|c|c|c|c|c|c|c|c|c|c|c|}
\hline \multirow{3}{*}{ Comp. } & \multirow{3}{*}{ M.F } & \multirow{3}{*}{ Yield } & \multirow{3}{*}{ m.p } & \multicolumn{8}{|c|}{ Elemental analysis } \\
\hline & & & & \multicolumn{2}{|c|}{$\% \mathrm{C}$} & \multicolumn{2}{|c|}{$\% \mathrm{H}$} & \multicolumn{2}{|c|}{$\% \mathrm{~N}$} & \multicolumn{2}{|c|}{$\% \mathrm{~S}$} \\
\hline & & & & Found & Calc. & found & Calc. & found & Calc. & found & Calc. \\
\hline $\mathrm{III}_{1}$ & $\mathrm{C}_{29} \mathrm{H}_{23} \mathrm{~N}_{5} \mathrm{O}_{5} \mathrm{~S}$ & $72 \%$ & $210^{\circ}$ & 62.90 & 62.92 & 4.17 & 4.19 & 12.64 & 12.65 & 5.78 & 5.79 \\
\hline $\mathrm{III}_{2}$ & $\mathrm{C}_{29} \mathrm{H}_{23} \mathrm{~N}_{5} \mathrm{O}_{5} \mathrm{~S}$ & $74 \%$ & $205^{\circ}$ & 62.91 & 62.92 & 4.21 & 4.19 & 12.66 & 12.65 & 5.80 & 5.79 \\
\hline $\mathrm{III}_{3}$ & $\mathrm{C}_{30} \mathrm{H}_{23} \mathrm{~N}_{4} \mathrm{O}_{5} \mathrm{SF}$ & $65 \%$ & $209^{\circ}$ & 63.15 & 63.15 & 4.06 & 4.06 & 9.82 & 9.82 & 5.62 & 5.62 \\
\hline $\mathrm{III}_{4}$ & $\mathrm{C}_{31} \mathrm{H}_{26} \mathrm{~N}_{4} \mathrm{O}_{5} \mathrm{~S}$ & $68 \%$ & $192^{\circ}$ & 65.73 & 65.71 & 4.60 & 4.62 & 9.90 & 9.89 & 5.68 & 5.66 \\
\hline $\mathrm{III}_{5}$ & $\mathrm{C}_{31} \mathrm{H}_{26} \mathrm{~N}_{4} \mathrm{O}_{5} \mathrm{~S}$ & $70 \%$ & $189^{\circ}$ & 65.69 & 65.71 & 4.63 & 4.62 & 9.87 & 9.89 & 5.65 & 5.66 \\
\hline $\mathrm{III}_{6}$ & $\mathrm{C}_{30} \mathrm{H}_{23} \mathrm{~N}_{5} \mathrm{O}_{7} \mathrm{~S}$ & $76 \%$ & $220^{\circ}$ & 60.31 & 60.29 & 3.89 & 3.88 & 11.74 & 11.72 & 5.39 & 5.37 \\
\hline
\end{tabular}




\section{ANTIMICROBIAL ACTIVITY}

A broad panel of microbes was used for testing the antibacterial and antifungal properties of the molecules synthesized. The samples were tested by standard protocols like micro-dilution method. Anti-bacterial tests were carried against gram positive and gram negative bacteria. The anti-fungal tests were carried against two fungal strains C.alibicans and A.Niger.

SAR Study

It was observed that the use of ele.withdrawing and ele. Donating group to confer different electronic environments on the molecules showed a great impact on biological activity. Compound III $_{3}$ and III $_{6}$ showed good activity.

\begin{tabular}{|c|c|c|c|c|}
\hline Compounds & E-Coli & B-subtilis & C.alibicans & A. Niger \\
\hline $\mathrm{III}_{1}$ & 31.2 & 34.3 & 125 & 62.5 \\
\hline $\mathrm{III}_{2}$ & 31.4 & 34.2 & 62.5 & 62.5 \\
\hline $\mathrm{III}_{3}$ & 58.5 & 62.5 & 250 & 250 \\
\hline $\mathrm{III}_{4}$ & 36.3 & 37.1 & 125 & 125 \\
\hline $\mathrm{III}_{5}$ & 31.2 & 31.2 & 250 & 125 \\
\hline $\mathrm{III}_{6}$ & 62.0 & 61.0 & 250 & 250 \\
\hline
\end{tabular}

\section{CONCLUSION}

We have synthesized a verity of chalcone bearing 1,3,4-oxadiazole derivatives. In general, compounds with electron withdrawing group showed good anti-bacterial and anti-fungal activity. The results promoted the titled compound chalcone containing oxadiazole as an interesting lead for further synthetic and biological evolution. These titled compounds were confirmed by spectral data.

\section{Acknowledgement}

Authors acknowledge thanks to Kalpesh Parikh, principal of Sheth M.N. patel Science College, Patan. Authors also thank to NFDD Centre for the analytical services and spectral services.

\section{References}

[1]. Rane, R.A.; Telekar, V.N. Bioorg.Med. Chem. Lett. 2010, 20, 5681-5685.

[2]. W.B. Geiger, J.E. Conn, J. Am. Chem. Soc. 1945,67,112-116.

[3]. Pandeya, S.N.; Sriram, D.; Nath, G.; DeClercq, E. Eur. J. Med. Chem. 1999, 9, 25-31.

[4]. Biradar, J.S.; Sasidhar, B.S.; Parveen, R. .Eur. J. Med. Chem. 2010, 45, 4074-4078.

[5]. Nowakowska, Z.. Eur. J. Med. Chem.2007, 42, 125-137.

[6]. Devi, J.M.; Ali, K.S.; Venkatraman, V.R.; Ramakrishnan, S.K.; Ramachandran, K. Therochim. Acta 2005, 438, 29-34.

[7]. Liu, M., Wilairat, P., \& Go, L. M. Journal of Medicinal Chemistry, 2010, 44, 4443.

[8]. Francesco, E., Salvatore, G., Luigi, M., \& Massimo, C. Phytochemistry, 2007, 68, 939.

[9]. T.J. Simpson,: R.H. Thomson (Ed.), The Chem. of Nat.Prod. Blackie, London, 1985

[10]. T.M.C. Tan, Y. Chen, K.H. Kong, J. Bai, Y. Li, S.G. Lim, T.H. Ang, Y. Lam, Antivir.Res. 2006, 71, 7-14.

[11]. S.L. Gaonkar, K.M.L. Rai, B. Prabhuswamy, Eur. J. Med. Chem.2006, 41,841-846.

[12]. A.S. Aboraia, H.M. Abdel-Rahman, N.M. Mahfouz, M.A. Gendy, Bioorg. Med. Chem.2006, 14, 1236-1246. 
[13]. Y. Li, J. Liu, H. Zhang, X. Yang, Z. Liu, Bioorg. Med. Chem. Lett. 2006, 16, 2278-2282.

[14]. C. Loetchutinat, F. Chau, S. Mankhetkorn, Chem. Pharm. Bull.2003, 51,728-730.

[15]. A.H. Abadi, A.A.H. Eissa, G.S. Hassan, Chem. Pharm. Bull.2003, 51,838-844.

[16]. M.T. Khan, M.I. Choudhary, K.M. Khan, M. Rani, A.U. Rahman, Bioorg. Med.Chem. 2005, 13, 3385-3395.

[17]. R.N. Warrener, Eur. J. Org. Chem.2000, 65, 3363-3380.

[18]. Vijay Patil, Kalpna.Tilekar, Sonali Mehendole-Munj, Rhea Mohan, C.S.Ramaa Eur. J. Med. Chem. 2010, 45,4539-4544. 